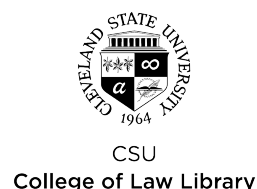

Cleveland State University

College of Law Library

\title{
Occupiers of 51 Olivia Road v. City of Johannesburg: Enforcing the Right to Adequate Housing through Engagement
}

Brian E. Ray

Cleveland State University, b.e.ray@csuohio.edu

Follow this and additional works at: https://engagedscholarship.csuohio.edu/fac_articles

Part of the Law Commons

How does access to this work benefit you? Let us know!

\section{Original Citation}

Brian Ray, Occupiers of 51 Olivia Road v. City of Johannesburg: Enforcing the Right to Adequate Housing through Engagement, 8 Human Rights Law Review 703 (2008)

This Article is brought to you for free and open access by the Faculty Scholarship at EngagedScholarship@CSU. It has been accepted for inclusion in Law Faculty Articles and Essays by an authorized administrator of EngagedScholarship@CSU. For more information, please contact research.services@law.csuohio.edu. 


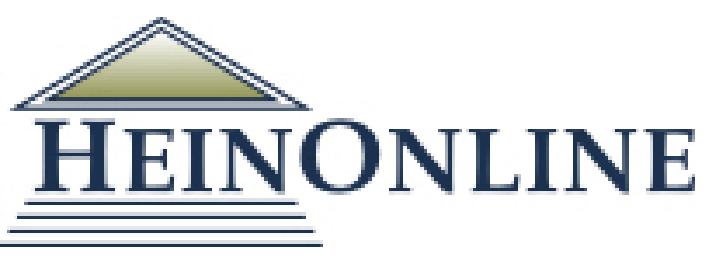

Content downloaded/printed from

HeinOnline

Mon Oct 14 14:32:53 2019

Citations:

Bluebook 20th ed.

Brian Ray, Occupiers of 51 Olivia Road v City of Johannesburg: Enforcing the Right to Adequate Housing through Engagement, 8 Hum. Rts. L. Rev. 703 (2008).

ALWD 6th ed.

Brian Ray, Occupiers of 51 Olivia Road v City of Johannesburg: Enforcing the Right to Adequate Housing through Engagement, 8 Hum. Rts. L. Rev. 703 (2008).

APA 6th ed.

Ray, B. (2008). Occupiers of 51 olivia road city of johannesburg: Enforcing the right to adequate housing through engagement. Human Rights Law Review 8(4), 703-713.

Chicago 7th ed.

Brian Ray, "Occupiers of 51 Olivia Road v City of Johannesburg: Enforcing the Right to Adequate Housing through Engagement," Human Rights Law Review 8, no. 4 (2008): 703-713

McGill Guide 9th ed.

Brian Ray, "Occupiers of 51 Olivia Road v City of Johannesburg: Enforcing the Right to Adequate Housing through Engagement" (2008) 8:4 Human Rights L Rev 703.

MLA 8th ed.

Ray, Brian. "Occupiers of 51 Olivia Road v City of Johannesburg: Enforcing the Right to Adequate Housing through Engagement." Human Rights Law Review , vol. 8, no. 4, 2008, p. 703-713. HeinOnline.

OSCOLA 4th ed.

Brian Ray, 'Occupiers of 51 Olivia Road v City of Johannesburg: Enforcing the Right to Adequate Housing through Engagement' (2008) 8 Hum Rts L Rev 703

Provided by:

Cleveland-Marshall College of Law Library

-- Your use of this HeinOnline PDF indicates your acceptance of HeinOnline's Terms and Conditions of the license agreement available at https://heinonline.org/HOL/License

-- The search text of this PDF is generated from uncorrected OCR text.

-- To obtain permission to use this article beyond the scope of your license, please use: Copyright Information

Use QR Code reader to send PDF to your smartphone or tablet device 
Human Rights Law Review 8:4 $\mathcal{O}$ The Author [2008]. Published by Oxford University Press. All rights reserved. For Permissions, please email: journals.permissions@oxfordjournals.org doi:10.1093/hrlr/ngn025 Advance Access publication 13 October 2008

\title{
Occupiers of 51 Olivia Road $v$ City of Johannesburg: Enforcing the Right to Adequate Housing through 'Engagement'
}

\author{
Brian Ray*
}

\section{Introduction}

On 19 February 2008, the South African Constitutional Court handed down an important new decision on socio-economic rights: Occupiers of 51 Olivia Road $v$ City of Johannesburg (City of Johannesburg). ${ }^{1}$ City of Johannesburg approved a landmark settlement between the City of Johannesburg and residents of several informal communities in Johannesburg who had sought to prevent the City from evicting them as part of an inner-city regeneration project. Rather than imposing a direct remedy, the Court instead constitutionalised a novel 'engagement' requirement in housing rights cases. Engagement, which requires government entities to consult with residents affected by policy decisions that may involve eviction and publicly report on that process, offers a novel and potentially powerful mechanism for enforcing socioeconomic rights that limits court intervention in policy decisions.

City of Johannesburg began as a series of emergency applications in the Witwatersrand High Court by the City of Johannesburg to evict over 300 people from six properties in inner-city Johannesburg. ${ }^{2}$ The City sought these evictions as part of broader regeneration strategy, one aspect of which was

*Assistant Professor of Law, Cleveland-Marshall College of Law, Cleveland, OH 44115. USA (brian.ray@law.csuohio.edu).

1 Occupiers of 51 Olivia Road, Berea Township and 197 Main Street Johannesburg $v$ City of Johannesburg and Others [2008] ZACC 1.

2 City of Johannesburg and Rand Properties (Pty) Ltd and Others, $2006(6)$ BCLR $728(\mathrm{w})$ at para. 2 (City of Johannesburg High Court). See Chenwi, 'Putting Flesh on the Skeleton: South African Judicial Enforcement of the Right to Adequate Housing of Those Subject to Evictions', (2008) 8 Human Rights Law Review 105, which provides a thorough analysis of this litigation prior to the Constitutional Court's final order. 
the identification, clearance and ultimate redevelopment of 'bad' buildings in the inner-city district. ${ }^{3}$ The National Building Regulations and Building Standards Act (NBRA), ${ }^{4}$ an apartheid-era law that grants municipalities the power to evict tenants of any building deemed unsafe or unhealthy, provided the legal basis for the City's emergency applications.

The residents of these buildings opposed the applications on several statutory and constitutional grounds, including the claim that the City's failure to provide access to adequate housing as required by section 26 of the South African Constitution precluded their eviction. ${ }^{5}$ The residents also counterclaimed, seeking, among other things, an order that the City's housing programme failed to comply with its constitutional and statutory duties. The residents sought a structural injunction requiring the City to comply with these duties. ${ }^{6}$

The residents' opposition was the result of a coordinated effort by a group of non-profit organisations working together on a range of efforts to protect the housing rights of poor communities throughout South Africa. Prior to the City's eviction attempts in these cases, the Geneva-based Centre on Housing Rights and Evictions (COHRE) published an extensive report criticising the City's eviction programme and outlining legal and policy arguments against that programme. ${ }^{7}$ COHRE partnered with several other organisations, including the Centre for Applied Legal Studies (CALS), to draft the report and ultimately defend the residents. ${ }^{8}$ The Community Law Centre, a public-interest research and advocacy group based at the University of the Western Cape, joined COHRE and CALS in filing amicus curiae briefs in support of the residents. ${ }^{9}$

The High Court focused exclusively on the section 26 arguments and, citing the Constitutional Court's first housing rights case, Government of the Republic of South Africa $v$ Grootboom, ${ }^{10}$ held that the City had failed to meet its obligations to create and implement a plan that would 'foster conditions to enable

3 For a description of the regeneration plan and the practice of forced evictions, see Centre on Housing Rights and Evictions (COHRE), Any Room for the Poor? Forced Evictions in Johannesburg, South Africa, 8 March 2005, at 41-6 and 60-4, available at:www.cohre.org/ view_page.php?page.id=120 [last accessed 20 August 2008].

4 No. 103 of 1977, section 12(4)(b). See generally, Chenwi, Advancing the Right to Adequate Housing of Desperately Poor People: City of Johannesburg v. Rand Properties', (2006) 14 Human Rights Brief 13; and COHRE, supra n. 3 at 38-9.

5 City of Johannesburg High Court, supra n. 2 at para. 11.7.

6 Ibid.

7 COHRE, supra n. 3.

8 Ibid. at 5, n. 1. See also COHRE/CALS, Media Release, 'Jo-Burg City Housing Policy Goes to Bloemfontein', 2 February 2007, which states: 'The plight of [the residents] was first brought to public attention in a May 2005 report co-authored by researchers from the Centre for Applied Legal Studies (CALS) and COHRE', available at: http://www.cohre.org/ view.page.php?pageid $=290$ [last accessed 20 August 2008].

9 Ibid. which states: 'The Centre for Housing Rights and Evictions (COHRE) and the Community Law Centre (CLC) have been permitted to make submissions [to the SCA] as friends of the court.'

10 2000 (11) BCLR 1169 (CC). 
the Respondents to have access to adequate housing in the inner city.11 The Court then ordered the City to develop and implement a "programme to progressively realise the right to adequate housing to people in the inner city of Johannesburg', and enjoined the City from evicting the residents. ${ }^{12}$

The residents' victory had an immediate impact. Despite appealing the judgment to the Supreme Court of Appeal (SCA), the City not only ceased its attempts to evict the residents who were party to the suit, but also put the entire inner-city eviction programme on hold. ${ }^{13}$

The SCA reversed the high court's judgment. The SCA held that the evictions were constitutional, but that the City had an obligation to provide the evicted residents with temporary housing consistent with recently passed national housing legislation. ${ }^{14}$ The SCA also found that the temporary accommodations must be within the municipal region but not the inner-city district, as requested by the residents and ordered by the High Court. ${ }^{15}$

The residents appealed the SCA's order to the Constitutional Court, which accepted the application in May 2007. ${ }^{16}$ The Court heard oral argument on 28 August 2007 and two days later issued an interim order. The order required the parties to 'engage with each other meaningfully ... in an effort to resolve the differences and difficulties aired in this application in light of the values of the Constitution, the constitutional and statutory duties of the municipality and the rights and duties of the citizens concerned. ${ }^{17}$ It also required that the parties file affidavits reporting the results of the negotiations with the Court approximately one month later, on 3 October $2007^{18}$

Just shy of the deadline, the parties filed affidavits with the Court outlining a remarkable settlement of most of the issues in the case. Among other things, the settlement requires the City to make the existing buildings safer and more habitable by cleaning the buildings and providing sanitation services, access to water and functioning toilets. ${ }^{19}$ Before relocating the residents from the buildings designated for redevelopment, the City agreed to refurbish several other buildings in inner-city Johannesburg to at least provide

11 City of Johannesburg High Court, supra n. 2 at para. 66.

12 Ibid. at Order, paras 3-4.

13 COHRE/CALS, Media Release, supra n. 8, which states: 'In light of the High Court's judgment, the City appears to have suspended its mass eviction program:

14 City of Johannesburg v Rand Properties (Pty) Ltd, 2007 SCA 25 (RSA), at para. 78 (City of Johannesburg $S C A$ ).

15 Ibid. at paras 75 and 77.

16 See Occupiers of 51 Olivia Road Berea Township and 197 Main Street Johannesburg $v$ City of Johannesburg. Case No. 24/07, Interim Order, 30 August 2007, available at: http://www.constitutionalcourt.org.za using search terms 'City of Johannesburg' [last accessed 24 August 2008].

17 Ibid. at para. 1.

18 Ibid. at para. 3.

19 Settlement agreement between City of Johannesburg and the Occupiers of 51 Olivia Road, Berea Township and 197 Main Street, Johannesburg, 29 October 2007, at paras 2-4 (City of Johannesburg partial settlement), copy on file with the author. 
'security against eviction; access to sanitation; access to potable water; access to electricity for heating, lighting and cooking ${ }^{20}$ and to limit any rental fees to no more than $25 \%$ of the occupants' monthly income. ${ }^{21}$ The City also agreed to consult with the residents on the 'provision of suitable permanent housing solutions...h having regard to applicable national, provincial and municipal housing policies. ${ }^{22}$

The Constitutional Court delivered its final opinion and order on 19 February 2008. The Court approved the parties' settlement but specifically refused to deal with the residents' broader claim that the City still lacked a comprehensive housing plan as required by Grootboom. Instead, the Court focused on the process that had resulted in the settlement and found that 'there is every reason to believe that negotiations will continue in good faith' including negotiations over permanent housing for the residents as part of a broader housing plan. ${ }^{23}$ The Court noted that the City's position had evolved considerably throughout the litigation as demonstrated by the City's 'willingness to engage' and expressed optimism that 'there is no reason to think that future engagement will not be meaningful and will not lead to a reasonable result: ${ }^{24}$ But the Court was also careful to emphasise that judicial intervention remains an enforcement option if this course becomes necessary, ${ }^{25}$

The Court then formalised the negotiation requirement that it had imposed on the parties in this case. The Court adopted the term 'engagement' to describe this requirement and spent 14 paragraphs of this 54-paragraph judgment explaining the need for engagement among the government, affected citizens and civil society organisations to develop effective policies for implementing the socioeconomic rights provisions in the Constitution.

The Court first situated the engagement requirement in its earlier cases, citing as examples the disappointment it had expressed in Grootboom over the City of Cape Town's failure to deal on a case-by-case basis with the problems faced by the Grootboom residents and also its call for 'respectful face-to-face engagement or mediation' in Port Elizabeth Municipality v Various Occupiers. ${ }^{26}$ The Court emphasised that engagement has the potential to contribute towards the resolution of disputes and to increased understanding and sympathetic care if both sides are willing to participate in the process. ${ }^{27}$

The Court found that a range of constitutional provisions, most importantly the right to human dignity and the right to life, require that the government 
'meaningfully engage' with citizens affected by its policies. ${ }^{28}$ The Court emphasised that, in most instances, engagement must be more then a merely 'ad hoc' process and instead any broad redevelopment planning effort must incorporate engagement from the start. ${ }^{29}$ The Court also recognised that 'people about to be evicted may be so vulnerable that they may not be able to understand the importance of engagement and may refuse to take part in the process. $^{30}$ In those circumstances, the State must still work to establish a meaningful engagement process. The Court emphasised that civil society has a significant role representing the interests of such persons: 'Civil society organizations that support the peoples' claims should preferably facilitate the engagement process in every possible way. ${ }^{31}$

Finally, the Court established what amounts to a public reporting requirement for the government following any engagement process. Emphasising that 'secrecy is counter-productive to engagement', the Court stated that, at least for municipal eviction proceedings, 'the provision of a complete and accurate account of the engagement process including at least the reasonable efforts of the municipality with that process would ordinarily be essential. ${ }^{32}$ Courts are then required to consider 'whether there had been meaningful engagement between a city and the resident about to be rendered homeless', when considering a challenge under section $26 .^{33}$

\section{Proceduralisation with Remedial Bite}

Many outside of South Africa have suggested that the relatively restrained approach to socioeconomic rights the Constitutional Court has developed to date strikes the correct balance between court enforcement and deference to legislative and executive policy judgments. The Court's first housing-rights case, Government of the Republic of South Africa v Grootboom, ${ }^{34}$ is the most celebrated example of this restraint. In Grootboom, the Court declared provincial and national housing policies unconstitutional, but limited its relief to a declaration with no specific guidance on how to remedy the defect. It also refused to retain jurisdiction to ensure government compliance. Minister of Health and Others v Treatment Action Campaign and Others (No 2), ${ }^{35}$ decided in 2002 where the Court ordered extension of a specific drug programme and

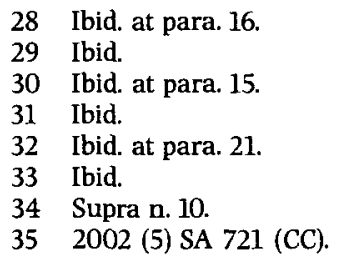


also Khosa and Others $v$ Minister of Social Development and Others, ${ }^{36}$ decided in 2003, where it ordered extension of social security benefits to permanent residents, are viewed as slightly stronger interventions but still relatively restrained in that the Court avoided broad interpretations of the rights at issue and continued to refuse to engage in direct oversight.

Grootboom has been described variously as a dialogic, ${ }^{37}$ or a 'weak-form',38 or an 'administrative-law' ${ }^{39}$ approach. These labels all highlight the Court's reluctance to engage directly in policy development, preferring to give broad discretion to the political branches while still indirectly enforcing these rights. For that same reason, critics of the Court's approach in Grootboom and these other early cases have charged it with proceduralising these rights by refusing to give them any substantive content. ${ }^{40}$

The Court's orders in City of Johannesburg demonstrate that it is firmly committed to leaving policy development in the hands of the political branches. Faced with consistent rulings at both the High Court and SCA levels ordering direct relief against the City of Johannesburg, the Court attempted one more time to force the parties to come up with their own solution to the apparent section 26 violations. In its final order, the Court then made the process that resulted in this remarkable settlement, a constitutional requirement in all eviction cases.

On first glance, this refusal to engage with the substance of section 26 appears to fulfil the worst fears of the Court's critics that these rights will become nothing more than 'good-government' standards without substantive content or effect. ${ }^{41}$ But the engagement process also offers the promise of something more than the Court's earlier cases. By forcing government officials to pay attention to section 26 on a consistent basis, even absent existing litigation, and also by recognising civil society's constitutional role in advocating for housing policy development, engagement may represent a powerful and innovative mechanism for enforcing socioeconomic rights.

On the one hand, the engagement requirement looks much like Grootboom. Like the declaration in that case, engagement gives the political branches

362004 (6) BCLR 569 (CC).

37 Dixon, 'Creating Dialogue about Socioeconomic Rights: Strong-form versus Weak-form Judicial Review Revisited', (2007) 5 International Constitutional Law Journal 391 at 417, argues that the Court should adopt a 'dialogic model', which is 'fully consistent with the approach the Court in TAC suggested might be appropriate in future cases'.

38 Tushnet, Weak Courts, Strong Rights: Judicial Review and Social Welfare Rights in Comparative Constitutional Law (Princeton: Princeton University Press, 2008) at 231-7.

39 Sunstein, Designing Democracy: What Constitutions Do (Oxford: Oxford University Press, 2001) at 234, states: 'What the South African Constitutional Court has basically done is to adopt an administrative law model of socioeconomic rights.' (emphasis added)

40 Brand, 'The Proceduralisation of South African Socio-Economic Rights Jurisprudence', in Botha et al. (eds), Rights and Democracy in a Transformative Constitution (Stellenbosch: Sun Media, 2003) 33 at 41 , describes the Court's approach as 'limited.

Ibid. at 49 . 
control over what benefits to offer under section 26, thus giving them the power to determine the substantive content of the housing right. In this way, engagement avoids court-directed policy making, at least at the outset, while still requiring specific attention to section 26 's requirements.

But other aspects of engagement offer a stronger remedial 'bite'. Under this new engagement requirement, local governments seeking to evict residents for any reason must now develop a process for consulting those residents. To be 'meaningful', as the Court requires, that process must offer real opportunity for negotiating a mutually acceptable solution that respects the right to adequate housing under section 26 . Civil society groups are specifically empowered to act as facilitators in this process, thus expanding the range of perspectives and enhancing the residents' bargaining power.

At its best, engagement will avoid the need for court involvement altogether. Over the short term, the municipality will be able to proceed, perhaps with some modifications to accommodate the residents, with whatever eviction plan it adopts. The displaced residents will be provided with some form of housing that may be, as was the case in City of Johannesburg, superior to the housing they give up.

In the long term, the engagement requirement can create incentives for government to develop the kind of multi-faceted and robust housing policies that section 26 arguably requires. The individual negotiations that engagement requires will presumably inform the content of any broader policies, and the results of these individual accommodations will form the basis for modifying that strategy over time.

Thus, engagement appears to have two, somewhat contradictory, effects. Engagement potentially diminishes the judiciary's interpretive role while, at the same time, enhancing its remedial authority. The Constitutional Court went to great lengths to avoid giving any specific content to the housing right itself in City of Johannesburg. This represents in many respects a retrenchment from Grootboom, where the Court was willing to find that section 26, at a minimum, requires a plan for addressing the emergency needs of homeless communities. The Court stopped short of defining what content such a plan must include, but did, at least, identify emergency needs as a substantive aspect of section 26 .

City of Johannesburg, in contrast, lapses almost completely into a procedural analysis and finds the City's eviction procedures lacking because the City failed to engage with residents before attempting eviction, not because it lacked a constitutionally adequate housing plan, as the residents claimed. While Grootboom's emergency-needs requirement was part of the basis for questioning that procedural failure, the Court deliberately avoided further elaboration of section 26's content. The Court thus appears to be moving more firmly into a role that avoids direct interpretation at all costs, rather than, as in other weak-form models, providing contingent interpretations 
that are subject to revision by the executive or legislature. This potentially weakens its interpretive authority even further than in earlier cases.

At the same time that the failure to give substantive content to section 26 represents a relinquishing of interpretive authority, however, the engagement requirement also represents a stronger remedy because the Court is now requiring municipalities to develop what is in effect a prospective report for court review of its engagement efforts. The genius of this structure is that it creates some of the benefits of a structural injunction because the government must now consider what a court's response will be in the same way that it would if it were operating under a consent decree but the court does not actually retain jurisdiction. Instead, the reporting function will come into play only in subsequent litigation. While that removes the immediacy of an injunction, it also broadens the effect because the City must create a broad-based reporting procedure and apply it in all cases, not just those that would be directly subject to an injunction.

This remedial 'ratcheting up' falls somewhere in between a declaration of unconstitutionality, to which the Court limited itself in Grootboom, and direct judicial enforcement of section 26 . This is so because engagement requires government action but does not mandate implementation of a particular substantive programme. Engagement is also a remedial enhancement in the sense that it at least implies an individually enforceable right, something that Grootboom expressly rejected. Again, the right is not to a particular service or level of benefit but to a procedure, thus avoiding a court-prescribed policy. But that procedure is plainly intended to result in specific benefits, at least in the form of retaining access to existing shelter, but more likely, as was the case in City of Johannesburg, some improved accommodation and a reasonable prospect for long-term access to permanent housing.

This aspect of engagement in particular makes the remedy at once more immediate, and, at the same time, avoids the problem of queue-jumping with which the Court was so concerned in previous cases. ${ }^{42}$ While residents whom a municipality seeks to evict will be the immediate beneficiaries of whatever accommodation results from engagement, the municipality controls that choice, and, presumably, will expend resources in engagement and accommodation only after deciding that broader policy goals will be served by targeting one community over another.

The engagement requirement also should force municipalities to incorporate housing needs as part of any long-term development strategy because

42 See, for example, Grootboom, supra n. 10 at para. 92, where the Court states: "This judgment must not be understood as approving any practice of land invasion for the purpose of coercing a state structure into providing housing on a preferential basis to those who participate in any exercise of this kind. Land invasion is inimical to the systematic provision of adequate housing on a planned basis.' 
they will not be able to evict anyone without such a plan in place. The Court explicitly emphasised this aspect when it rejected the City's claim that it would be impractical to expect meaningful engagement in every eviction case in inner-city Johannesburg. ${ }^{43}$ The Court also noted that smaller municipalities may be able to engage with residents on only an ad hoc basis, but large cities require a long-term strategy for 'structured, consistent and careful engagement: ${ }^{44}$

Viewed this way, engagement starts to look a lot more robust than even Grootboom, which mandated a particular shift in housing policy but put no short-term procedure in place for ensuring a prompt response. Engagement stands as a background requirement, potentially, but not immediately, enforceable by the courts. This removes the courts from direct policy development but gives them enhanced remedial power because municipalities face the prospect of defending not only the ultimate substantive policy they develop but also the process through which they implement that policy.

Rather than creating a dialogue between courts and these municipalities in the sense that both sides offer a series of interpretations and reinterpretations of the right itself, engagement really creates a mechanism for requiring those municipalities to pay consistent attention to the right to housing and to develop plans that address the housing crisis. While focused on evictions specifically, this mechanism has potentially broader effects. Whenever government at any level desires to implement redevelopment policies that may involve displacement it must engage with them and interested civil society groups.

Mark Tushnet notes that what gives rights a feeling' of strength or weakness depends to a large degree on the extent to which such rights generate distinctive political claims. ${ }^{45}$ By this definition, engagement feels relatively stronger than the declaration in Grootboom precisely because it puts in place the enforcement mechanism just described. Those political claims are strengthened because the Court explicitly extended them beyond citizens whom municipalities seek to evict to civil society groups involved in housing advocacy. While engagement will work most directly in the context of a proposed eviction, the Court's recognition of the constitutional role that civil society will play in that context strengthens their hand in the larger policy development process. Municipalities now know that they must consult these groups whenever they seek to evict and must seriously consider what those groups think section 26 requires. Thus, it makes sense for those same municipalities to take seriously those groups' views when developing housing policy more generally.

The specific role for civil society groups that the Court recognises also helps alleviate concerns that the Court's refusal to enforce these rights directly 
means that only those individuals who can gain access to the legal assistance of the kind afforded to the City of Johannesburg plaintiffs will benefit. Tushnet points out that, to be an effective substitute for direct court enforcement, civil society groups must gain domestic legitimacy. ${ }^{46}$ The Court's direct recognition goes a long way towards establishing that legitimacy, not only in broader society but also with the political branches, which must now deal with these groups consistently over time.

Rather than dialogue in the sense that term is typically understood, in the form of a conversation between courts and the political branches, then, engagement forefronts the interaction among civil society, citizens and the government. The courts play only a supporting role.

\section{Conclusion}

City of Johannesburg represents an important new development in the Constitutional Court's approach to enforcement of socio-economic rights. On the one hand, it appears to confirm predictions by the Court's critics that it is proceduralising these rights. But, at the same time, engagement offers a novel and potentially more powerful tool for enforcement through proceduralisation that those critics failed to anticipate. Accordingly, City of Johannesburg can be read as signalling a continued willingness by the Court to give the government not only broad leeway in policy development but also an increasing impatience over the pace of that development and the level of commitment to implementation of these rights.

It is far too early to predict precisely how (and whether) municipalities and other levels of government involved in housing policy will attempt to comply with this new engagement requirement. It is likely, however, that engagement will have several important effects over the short term. First, engagement should strengthen the role of civil society groups both by heightening their profile with the executive during the policy development process and by increasing their leverage when particular disputes arise.

Second, lower courts now have a broader role to play when dealing with housing policy disputes. This is because courts are now specifically empowered to review the entire process that led up to the dispute, including to what extent the government responded to City of Johannesburg by developing a mechanism for engaging citizens affected by their policies.

Finally, there is good reason to expect that the Constitutional Court might extend the engagement requirement to situations beyond eviction. The Witwatersrand High Court's recent water-rights decision is a scenario ripe 
for such an extension. ${ }^{47}$ In that decision, the High Court ruled that the City of Johannesburg's practice of forced installation of pre-payment water meters in Phiri (one of the oldest townships of Soweto) was unconstitutional and ordered the City to provide residents of Phiri with 50 litres of free basic water per person per day, setting aside the City's decision to limit free water to 25 litres per person per day. ${ }^{48}$ Key to the court's judgment was a finding that the City implemented its prepayment meter policy without any meaningful consultation with the affected residents. ${ }^{49}$ It is conceivable that the Constitutional Court, which is required under the Constitution to affirm the order, might instead order the City to return to the bargaining table to engage further with the Phiri residents rather than merely affirming the specific water policy crafted by the High Court. Doing so would confirm the Court's move towards a procedural approach to enforcement to the disappointment of its critics but would also open the door to extending the remedial 'bite' of engagement to the other socioeconomic rights in the South African Constitution.

47 Mazibuko and Others v City of Johannesburg and Others, Case No. 06/13865, 30 April 2008, (Witwatersrand Local Division). available at: http://www.idasa.org.za/index.asp?page= outputdetails.asp\%3FRID\%3D1454\%26OTID\%3D5\%26PID\%3D45 [last accessed 24 August 2008].

48 Ibid. at para. 183.

49 Ibid. at para. 122. 